Research Article

\title{
Modified use of microbial technology as an effective enhanced oil recovery
}

Correspondence:
Sudad H AL-Obaidi
drsudad@gmail.com

Publication Date:

15 Fabruary 2004

\section{Keywords:}

MEOR, Tertiary,

Microorganism,

Microflora, EOR.

\begin{abstract}
AL-Obaidi SH
Assistant Professor, Petroleum Eng. Dept., Mining Institute.
\end{abstract}

\begin{abstract}
The tasks of applying new technologies of oil production are urgent. These technologies must significantly be able to increase the oil recovery of already developed formations, where it is no longer possible to extract significant residual oil reserves by traditional methods. Among these technologies is the microbial enhanced oil recovery method (MEOR). It is a tertiary crude oil recovery technology that allows partial recovery of residual oil that cannot be recovered by primary and secondary methods, thereby extending the life of developed oil reservoirs. MEOR is based on the activation of reservoir microflora. A special group of hydrocarbonoxidizing microorganisms is able to metabolize hydrocarbons, producing organic solvents such as alcohols and aldehydes, fatty acids with surface activity, gaseous products and other metabolites that increase the mobility of oil.
\end{abstract}

\section{Introduction}

Enhanced oil recovery and intensification of oil production processes remain the problems of the domestic and global oil industry.

In the middle of the 20th century, methods of enhanced oil recovery with the use of microorganisms were developed [1][2][3][4]. The use of MEOR - microbial enhanced oil recovery methods is currently relevant, since they have multifunctional properties of impact on the formation, allowing effective recovery of residual oil at late stages of field development.

The idea of using bacteria to displace oil from porous media was suggested back in 1926 by Beckman . In 1954, experimental work was initially carried out in the United States, North Carolina at the Lisbon field [5][6]. A little later, in the $80 \mathrm{~s}$, significant research activity in this direction was noted in the USSR, Czechoslovakia, Hungary, Poland and Azerbaijan, where the injection of anaerobic bacteria in oil fields also took place [7][8].

Despite the fact that petroleum microbiology as a field of science was formed 80 years ago, information on the microflora of the oil reservoir is still fragmentary. It is well known that oil fields are inhabited by enzymatic, sulfate -, sulfur - and iron-reducing bacteria, as well as acetate and methane-producing bacteria.

Microbial methods of enhanced oil recovery are used by different oil companies. Among which, Titan Oil Recovery Inc., Glori Energy in cooperation with Statoil, Total, Du Pont in cooperation with $\mathrm{BP}$ and Chevron. TATNEFT is one of the most Russian oil companies that actively using microbiological methods. 
At the same time, the geography of application of these methods of enhanced oil recovery is extensive: the USA, Canada, Brazil, Bulgaria, Azerbaijan, Romania, Germany, Russia, etc.

Also in East Asia, experimental industrial tests were registered in China, Malaysia, India and Indonesia [9][10].

Development of oil fields using waterflooding entails the appearance of oxygen in the reservoir and leads to the development of aerobic microorganisms.

\section{Methodology}

Studies conducted in the last few years in the oil fields of the Russian Federation have shown the possible existence of a reservoir microbial community[11][12][13][14]. This information can serve as a theoretical basis for the development of a new microbial method for enhanced oil recovery.

The method consists in injecting an aerated aqueous solution of nitrogen and phosphorus mineral salts into the formation. This process will lead to the activation of the formation microflora, mainly oil-oxidizing bacteria responsible for the partial oxidation of residual oil and producing alcohols, fatty acids, surfactants, carbon dioxide and others compounds. These metabolites and microbial biomass, in turn, are used by enzymatic and methane-producing bacteria as substrates, which are subsequently produced. In the presence of sulphates, part of the oxidized substance is used by sulphate-reducing bacteria.

The proposed biotechnology was tested in different oil fields in reservoirs with temperatures ranging from 20 to $45^{\circ} \mathrm{C}$. Microbiological methods of enhanced oil recovery have not been used in practice in high-temperature oil fields [15][16][17].

However, it has been experimentally confirmed that a high-temperature oil reservoir is a complex ecosystem in which the microbial community interacts with the non-living environment in such a way that the energy flow generates a certain trophic system. The results demonstrate the high efficiency of biotechnology for improving oil recovery by microbial method based on the activation of reservoir microflora in an oil field with high temperature. The microbial method of enhanced oil recovery at high temperatures was applied in the horizons of the northern section of the Kondyan formation of the Dagan field in China [18][19].

\section{Conclusions}

The use of the technology of microbiological action allows us to speak about its advantages, such as: low costs for processing, environmental safety, high technological efficiency.

Under reservoir conditions, the products of bacterial biosynthesis can increase the mobility of oil by reducing its viscosity and reducing the interfacial tension at the interface, which improves the separation of oil from the formation rock.

High efficiency of biotechnology for improving oil recovery by microbial method based on the activation of reservoir microflora in an oil field with high temperature.

Also, organic acids and carbon dioxide released by microorganisms contribute to a change in the flow - volumetric properties of the oil reservoir [20][21][22]. 


\section{References}

[1]. Shennan, J. L. and Vance, I.( 1987). "Microbial Enhanced Oil Recovery Techniques and Offshore Oil Production".

[2]. Al-Obaidi, Sudad H. and Guliaeva NI. (2002). "Determination of Flow and Volumetric Properties of Core Samples Using Laboratory NMR Relaxometry." engrXiv,10.31224/osf.io/t46wj.

[3]. Moses, V. and Springham, D. G. (1982).Bacteria and the Enhancement of Oil Recovery, Applied Science Publishers, New Jersey.

[4]. Bryant, RS and Burchfield, TE (1989). Review of Microbial Technology for Improving Oil Recovery. SPE Reservoir Eng., May 151.

[5]. Al-Obaidi, Sudad H.(1996). "Разработка Методики И Технологии Обработки Данных ГИС И Керна Для Определения Подсчетных Параметров Нефтегазовых Месторождений Ирака : На Прим. Месторождения Вост. Багдад." OSF Preprints, 10.31219/osf.io/f6vka .

[6]. Hitzman, DO and et al. (2003) Innovative MIOR Process Utilizing Indigenous Reservoir Constituents, Final Technical Reports.

[7]. Bryant, RS and Douglas, J (1988). Evaluation of Microbial Systems in Porous Media for EOR, SPE Reservoir Eng., May, 489-495.

[8]. Al-Obaidi, Sudad H. and Аль Обейди, Судад Х. (1996).“ ОПРЕДЕЛЕНИЕ ГЛИНИСТОСТИ ПРОДУКТИВНЫХ ПЛАСТОВ МЕСТОРОЖДЕНИЙ НЕФТИ И ГАЗА ВОСТОЧНОГО БАГДАДА." OSF Preprints, 10.31219/osf.io/dmw9c .

[9]. Jack, TR (1988). Microbially Enhanced Oil Recovery, Biorecovery 1: 59-73.

[10]. Jack, TR and Stehmeier, LG (1998). Selective Plugging of Water Injection Wells In: Bucherfiled TE, Bryant RS, (Eds.), Proc.US DOE Conference 870858, Natl. Technical Information Service Symposium on Application of Microorganisms to Petroleum Technology Springfield, VA.

[11]. Al-Obaidi, Sudad H.(1990). "Comparison of Different Logging Techniques for Porosity Determination to Evaluate Water Saturation." engrXiv,10.31224/osf.io/fvj9u .

[12]. Khire, JM and Khan, MI (1994) Microbially Enhanced Oil Recovery (MEOR). Part I, Importance and Mechanism of MEOR, Enzyme Microbiol, Tech, 16: 170-2.

[13]. Adkins, JP and et al. (1992). Microbially Enhanced Oil Recovery from Unconsolidated Limestone Cores, Geomicrobiology J.,10: 77-86

[14]. Al-Obaidi, Sudad H. (1996). “Разработка Методики И Технологии Обработки Данных ГИС." OSF Preprints, 10.31219/ osf.io/e68us .

[15]. Lappin-Scott, HM and etal.(1988). Nutrient Resuscitation and Growth of Starved Cells in Sandstone Cores a Novel Approach to Enhanced Oil Recovery Appl. Environ, Microbiol, 54: 1373-1382. 
[16]. Al-Obaidi, Sudad H.(1998). "Areas of Effective Application of Submersible Centrifugal Pump Installations with and Without a Gas Separator." engrXiv, 10.31224 osf.io/2c84h .

[17]. Youssef, $\mathrm{NH}$ and et al. (2004). Comparison of Methods to Detect Biosurfactant Production by Diverse Microorganisms. J. Microbiol, Methods 56: 339-347.

[18]. Al-Obaidi, Sudad H. (1996). "Модификация Уравнения Арчи Для Определения Водонасыщенности Нефтяного Месторождения Восточный Багдад." OSF Preprints, 10.31219/ osf.io/tqpn5 .

[19]. Jenneman, GE and et al. (1984). Experimental Studies of In Situ Microbial Enhance Oil Recovery, Soc. Pet. Eng. J. Feb. 33-37.

[20]. Al-Obaidi, Sudad H.(1999). "Submersible Screw Pumps in Oil Industry."engrXiv, 10.31224/ osf.io/zqu3c .

[21]. Hitzman, DO (1991). Microbial Enhanced Oil Recovery-The Time is Now. Developments in Petroleum Science 31: 11-20.

[22]. Al-Obaidi, Sudad H., Patkin AA, and Guliaeva NI. 2020. "Advance Use for the NMR Relaxometry to Investigate Reservoir Rocks." OSF Preprints,10.31219/osf.io/jmb9t . 